\title{
Density Functional Study of Calcium Nitride: Refined Geometries and Prediction of High-Pressure Phases
}

\author{
S. Rebecca Römer, ${ }^{\dagger}$ Wolfgang Schnick, ${ }^{\dagger}$ and Peter Kroll*, \\ Department Chemie and Biochemie, Lehrstuhl für Anorganische Festkörperchemie, \\ Ludwig-Maximilians-Universität München, Butenandtstrasse 5-13 (D), D-81377 München, Germany, and \\ Department of Chemistry and Biochemistry, The University of Texas at Arlington, 700 Planetarium Place, \\ Arlington, Texas 76019-0065
}

Received: August 29, 2008; Revised Manuscript Received: December 2, 2008

\begin{abstract}
The high-pressure behavior of $\mathrm{Ca}_{3} \mathrm{~N}_{2}$ is studied up $100 \mathrm{GPa}$ using density functional theory. Evaluation of many hypothetical polymorphs of composition $\mathrm{A}_{3} \mathrm{X}_{2}$ leads us to propose four high-pressure polymorphs for both $\alpha$ - and $\beta-\mathrm{Ca}_{3} \mathrm{~N}_{2}$ : (1) an anti- $\mathrm{Rh}_{2} \mathrm{O}_{3}-\mathrm{II}$ structure at $5 \mathrm{GPa}$, (2) an anti-B-sesquioxide structure at $10 \mathrm{GPa}$, (3) an anti-A-sesquioxide structure at $27 \mathrm{GPa}$, and (4) a hitherto unknown hexagonal structure $\left(\mathrm{Pb}_{3} / \mathrm{mmc}\right)$, derived from the post-perovskite structure of $\mathrm{CaIrO}_{3}$, at $38 \mathrm{GPa}$. The development of the density and bulk modulus under pressure has been examined.
\end{abstract}

\section{Introduction}

$\mathrm{Ca}_{3} \mathrm{~N}_{2}$ has been known for over 100 years, and its synthesis was reported as early as 1898 by Moissan. ${ }^{1}$ It is widely used as a starting material for the synthesis of multinary nitrides or as a flux. ${ }^{2}$ In industry, $\mathrm{Ca}_{3} \mathrm{~N}_{2}$ finds application-among others-as an additive in the refinement process of steel ${ }^{3}$ and as a catalyst for the transformation of hexagonal $\mathrm{BN}$ into cubic $\mathrm{BN} .{ }^{4}$

Three different structural modifications of $\mathrm{Ca}_{3} \mathrm{~N}_{2}$ have been discussed in the literature: (1) $\alpha-\mathrm{Ca}_{3} \mathrm{~N}_{2}$ (maroon or yellow, cubic, synthesized at $T>700{ }^{\circ} \mathrm{C}$ ), (2) " $\beta-\mathrm{Ca}_{3} \mathrm{~N}_{2}$ " (black, hexagonal or tetragonal, synthesized at $T<700{ }^{\circ} \mathrm{C}$ ), and (3) HP/HT-Ca $\mathrm{N}_{2}$ (orthorhombic, synthesized at $1800{ }^{\circ} \mathrm{C}$ and $46 \mathrm{kbar}$ )..$^{5-8}$ The structure of $\alpha-\mathrm{Ca}_{3} \mathrm{~N}_{2}$ (anti-bixbyite; $\mathrm{C}$-sesquioxide) has been proposed early on. ${ }^{8,9}$ The true nature of " $\beta-\mathrm{Ca}_{3} \mathrm{~N}_{2}$ " has recently been questioned. It apparently is a $\mathrm{Na}-\mathrm{Ca}-\mathrm{N}$ compound, possibly a $\mathrm{Na}-\mathrm{Ca}$ subnitride. ${ }^{10}$ The description of the HP/HT phase of $\mathrm{Ca}_{3} \mathrm{~N}_{2}$ by Bradley et al. ${ }^{7}$ is, unfortunately, the only reference addressing synthesis and characterization of this modification in the literature. The continuing interest in $\mathrm{Ca}-\mathrm{N}$ compounds then is manifested in the recent synthesis of a new modification of $\mathrm{Ca}_{3} \mathrm{~N}_{2}$ at 200 and $420{ }^{\circ} \mathrm{C}$ from the elements or from $\mathrm{Ca}_{2} \mathrm{~N}$ and $\mathrm{N}_{2}$ by Höhn. ${ }^{11}$ Careful structural characterization revealed a hexagonal (corundum) structure. As a second phase of $\mathrm{Ca}_{3} \mathrm{~N}_{2}$ established beyond doubts, this modification was termed $\beta-\mathrm{Ca}_{3} \mathrm{~N}_{2}$.

The relation of $\alpha$ - and $\beta-\mathrm{Ca}_{3} \mathrm{~N}_{2}$ to the anti-structures of some sesquioxides motivates the search of potential high-pressure phases of $\mathrm{Ca}_{3} \mathrm{~N}_{2}$ among the (anti-)HP-phases of $\mathrm{M}_{2} \mathrm{O}_{3}$ oxides, which exhibit a very rich high-pressure chemistry. Recent advances in instrumentation and characterization have shown a tremendous amount of new discoveries. For example, $\mathrm{Mn}_{2} \mathrm{O}_{3}$, bixbyite, transforms into the post-perovskite structure $\left(\mathrm{CaIrO}_{3}{ }^{-}\right.$ type) at 27-38 GPa. ${ }^{12}$ Besides the post-perovskite structure type, the $\mathrm{Rh}_{2} \mathrm{O}_{3}-\mathrm{II}$ and the perovskite structure are also widely discussed high-pressure candidates for several sesquioxides. Many binary oxides with a corundum structure at ambient

* Corresponding author. Phone: (+1)-817-272-3814. Fax: $(+1)-817-272-$ 3808. E-mail: pkroll@uta.edu.

† Ludwig-Maximilians-Universität München.

* The University of Texas at Arlington. pressure have been found to undergo phase transformations first into a $\mathrm{Rh}_{2} \mathrm{O}_{3}$-II structure, then further at even higher pressures into a perovskite and post-perovskite modification. ${ }^{13-26}$ Corundum $\left(\alpha-\mathrm{Al}_{2} \mathrm{O}_{3}\right)$ itself transforms into $\mathrm{Rh}_{2} \mathrm{O}_{3}-\mathrm{II}$ at $80-100 \mathrm{GPa}$ and is predicted to undergo a second phase transformation at 131-156 GPa, which has been recently observed at 130 GPa. ${ }^{13-22}$ The higher homologue $\operatorname{In}_{2} \mathrm{O}_{3}$ has been predicted to exhibit a transformation from bixbyite to $\mathrm{Rh}_{2} \mathrm{O}_{3}-\mathrm{II}$ at $10 \mathrm{GPa}$ and further to post-perovskite at about $45 \mathrm{GPa} .{ }^{27}$ Most recent experiments confirm the prediction of the $\mathrm{Rh}_{2} \mathrm{O}_{3}$-II phase for both $\mathrm{Ga}_{2} \mathrm{O}_{3}$ and $\mathrm{In}_{2} \mathrm{O}_{3} .{ }^{28}$ Hematite $\left(\mathrm{Fe}_{2} \mathrm{O}_{3}\right)$ exhibits both phase transformations, into $\mathrm{Rh}_{2} \mathrm{O}_{3}-\mathrm{II}$ at $50-56 \mathrm{GPa}$ and into postperovskite at $65 \mathrm{GPa}^{24,26}$

These studies and the existence of a not further characterized $\mathrm{HP} / \mathrm{HT}-\mathrm{Ca}_{3} \mathrm{~N}_{2}$ phase prompted our endeavor to investigate the structural behavior of $\mathrm{Ca}_{3} \mathrm{~N}_{2}$ at high pressures. Naturally, we focused on the aforementioned high-pressure phases of bixbyite and sesquioxides, but did an extensive survey of other potential candidate structures.

\section{Method}

Structural optimizations, total energies, and properties are calculated within density functional theory (DFT), ${ }^{29}$ for which we use the Vienna ab initio simulation package (VASP). It combines the total energy pseudopotential method with a planewave basis set. ${ }^{30-32}$ The electron exchange and correlation energy is treated within the generalized gradient approximation (GGA). ${ }^{33}$ We employ the projector-augmented-wave (PAW) method. ${ }^{34}$ The cutoff energy for the expansion of the wave function into the plane wave basis is $500 \mathrm{eV}$. Residual forces are converged below $5 \times 10^{-3} \mathrm{eV} / \AA$. The Brillouin-zone integration is done via the Monkhorst-Pack scheme. ${ }^{35}$

Structure optimizations are obtained through relaxation of all structural parameters, positions as well as cell parameters. The unit cell of $\alpha-\mathrm{Ca}_{3} \mathrm{~N}_{2}$ contains 80 atoms, corresponding to 16 formula units. We compute this structure using the conventional unit cell and a $2 \times 2 \times 2 k$-point mesh. The unit cell of $\beta$ - $\mathrm{Ca}_{3} \mathrm{~N}_{2}$ contains 30 atoms (six formula units). A $k$-point mesh of $6 \times$ $6 \times 2$ is used for the optimization. The unit cell of $\gamma-\mathrm{Ca}_{3} \mathrm{~N}_{2}$ (anti- $\mathrm{Rh}_{2} \mathrm{O}_{3}-$ II structure) comprises 20 atoms, and we use an 


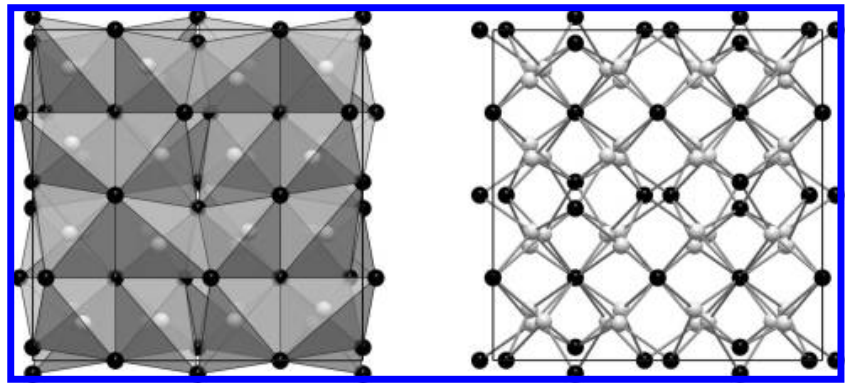

Figure 1. Anti-bixbyite structure of $\alpha-\mathrm{Ca}_{3} \mathrm{~N}_{2}$-view along [100] (Ca atoms are depicted in light gray, $\mathrm{N}$ atoms are black). On the left side, $\mathrm{CaN}_{4}$ tetrahedra are shown.

$8 \times 8 \times 4 k$-point mesh. For $\delta$ - $\mathrm{Ca}_{3} \mathrm{~N}_{2}$ (anti-B-sesquioxide structure; 30 atoms in the unit cell) a $2 \times 4 \times 6 k$-point mesh was employed. The unit cell of $\varepsilon-\mathrm{Ca}_{3} \mathrm{~N}_{2}$ (anti-A-sesquioxide structure) contains five atoms, the $c / a$ ratio was fixed at 1.29, and a $k$-point mesh of $6 \times 6 \times 4$ is used. Finally, for $\lambda-\mathrm{Ca}_{3} \mathrm{~N}_{2}$, a new potential high-pressure phase that emerged out of several candidates and is derived from the anti-post-perovskite structure, we employed an $8 \times 8 \times 4 k$-point mesh for the structure which contains 10 atoms 2 formula units). Although we present these relevant structures in detail, we note that we computed a wide selection of about two-dozen candidate structures with composition $\mathrm{Ca}_{3} \mathrm{~N}_{2}$.

Our choice of the GGA functional is based on the experience that it describes significantly better the relative energies of structures with different coordination of the atoms. Since our target is to study structures and structural transformations at high pressures, it is the better choice in comparison to the local density approximation (LDA). Therefore, although we controlled all our calculations within the LDA as well, all enthalpy differences and transition pressures given in this publication are based on GGA calculations.

To obtain the bulk modulus the volume is varied around the zero-pressure volume $V_{0}$, and the calculated energies are fitted to Murnaghans equation of state (EOS). ${ }^{36}$ The $E-V$ diagrams are transformed easily to give enthalpy versus pressure diagrams. We extract the pressure $p$ from the $E-V$ graph by numerical differentiation of the equations of state. The enthalpy $H$ is calculated via $H=E+p V$.

In equilibrium a system will adopt the structure with the lowest Gibbs energy $G$. A phase transformation is therefore governed by the difference of Gibbs energy: $\Delta G=\Delta H-T \Delta S$. The contributions of entropy differences are usually neglected. This is justified, because differences in entropy between extended solid-state structures are small in comparison to changes of $\Delta H$ within a few gigapascals of pressure change. Therefore, the enthalpy difference $\Delta H$ is a good measure to compare the relative stability of solid-state structures under pressure.

However, if variations from the ideal crystal structure occur, e.g., defects or disorder among atoms, entropic effects may become significant enough to impact the sequence of phases that appear in a phase diagram. We do not treat such terms in our study but will have to take them into account when comparing experimental and computational results.

\section{Results}

III.a. Optimized Structures. We computed a wide selection of candidate structures with composition $\mathrm{Ca}_{3} \mathrm{~N}_{2}$. Six polymorphs prove to be relevant for being considered in the phase diagram. $\alpha-\mathrm{Ca}_{3} \mathrm{~N}_{2}$ (Figure 1) adopts an anti-bixbyite structure, space group

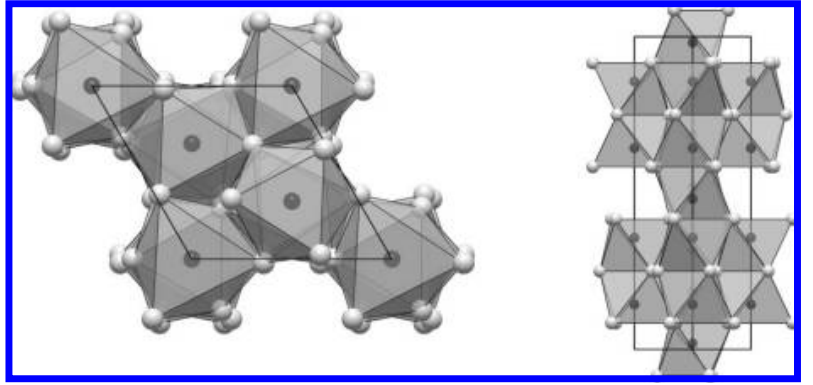

Figure 2. Anticorundum structure of $\beta-\mathrm{Ca}_{3} \mathrm{~N}_{2}$ (Ca atoms are depicted in light gray, $\mathrm{N}$ atoms are black; in both pictures $\mathrm{NCa}_{6}$ octahedra are drawn; left side, view along [001]; right side, view along [ $\left.\begin{array}{llll}-0.5 & 0.5 & 0\end{array}\right]$ ).

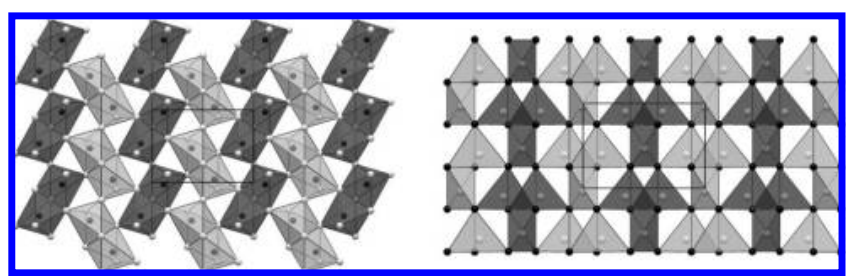

Figure 3. Anti- $\mathrm{Rh}_{2} \mathrm{O}_{3}-\mathrm{II}$ structure of $\gamma-\mathrm{Ca}_{3} \mathrm{~N}_{2}(\mathrm{Ca}$ atoms are depicted in light gray, $\mathrm{N}$ atoms are black; left side, $\mathrm{NCa}_{6}$ octahedra layer viewed along [001]; right side, $\mathrm{CaN}_{4}$ tetrahedra viewed along [010]).

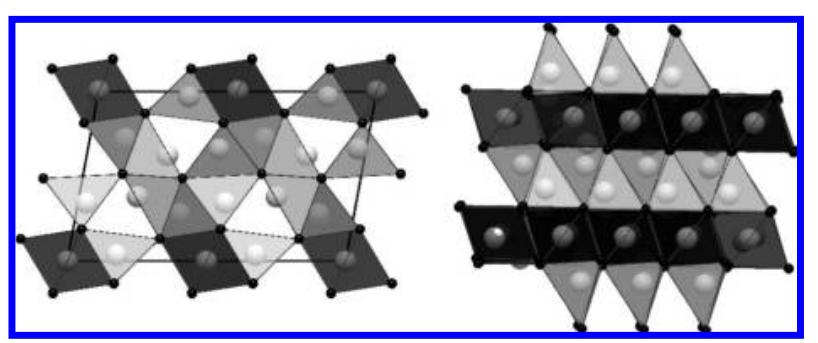

Figure 4. Anti-B-sesquioxide structure of $\delta-\mathrm{Ca}_{3} \mathrm{~N}_{2}(\mathrm{Ca}$ atoms are depicted in light gray, $\mathrm{N}$ atoms are black; left side, view along [010]; right side, view along $\left[\begin{array}{lll}1 / 3 & 1 & 2\end{array}\right]$; note the similarity to Figure 5 , right side $\varepsilon-\mathrm{Ca}_{3} \mathrm{~N}_{2}$ ).

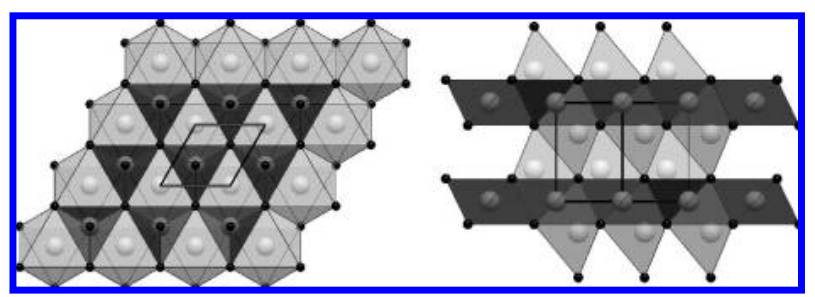

Figure 5. Anti-A-sesquioxide structure of $\varepsilon-\mathrm{Ca}_{3} \mathrm{~N}_{2}(\mathrm{Ca}$ atoms are depicted in light gray, $\mathrm{N}$ atoms are black; left side, view along [001]; right side, view along $[1 / 21 / 20]$; note the similarity to Figure 4 , right side $\delta-\mathrm{Ca}_{3} \mathrm{~N}_{2}$ ).

Ia $\overline{3}$ (no. 206). ${ }^{37} \beta-\mathrm{Ca}_{3} \mathrm{~N}_{2}$ crystallizes in the trigonal space group $R \overline{3} c$ (no. 167) in the anti- $\mathrm{Al}_{2} \mathrm{O}_{3}$ structure (Figure 2). ${ }^{11}$ The third candidate structure we find adopts an orthorhombic anti$\mathrm{Rh}_{2} \mathrm{O}_{3}$-II structure, space group Pbna (no. 60) (see Figure 3). ${ }^{23}$ Anticipating our results and the discussion, we denote this polymorph as $\gamma-\mathrm{Ca}_{3} \mathrm{~N}_{2}$. All these three structures comprise $\mathrm{Ca}$ atoms tetrahedrally coordinated by $\mathrm{N}$ and $\mathrm{N}$ atoms in octahedral coordination by $\mathrm{Ca}$. The fourth structure-denoted $\delta-\mathrm{Ca}_{3} \mathrm{~N}_{2}-$ exhibits the monoclinic B-sesquioxide structure (space group $C 2 / m$, no. 12$)^{38}$ (Figure 4 ), and the fifth structure-denoted $\varepsilon-\mathrm{Ca}_{3} \mathrm{~N}_{2}$-exhibits the trigonal A-sesquioxide structure (space group $P \overline{3} m 1$, no. 164$)^{39}$ (Figure 5). In $\delta-\mathrm{Ca}_{3} \mathrm{~N}_{2}$ the coordination numbers of $\mathrm{Ca}$ and $\mathrm{N}$ are partially increased. Whereas in $\alpha-$, $\beta$-, and $\gamma-\mathrm{Ca}_{3} \mathrm{~N}_{2} \mathrm{Ca}$ is always tetrahedrally and $\mathrm{N}$ octahedrally 


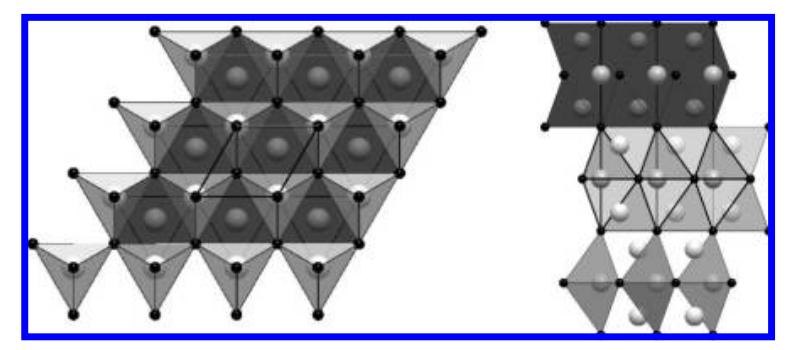

Figure 6. Structure of $\lambda-\mathrm{Ca}_{3} \mathrm{~N}_{2}$ (Ca atoms are depicted in light gray, $\mathrm{N}$ atoms are black; left side, view along [001], $\mathrm{CaN}_{6}$ octahedra are depicted in black, $\mathrm{CaN}_{5}$ trigonal bipyramids are light gray; right side, view along [0.5 0.5 0], interpenetrating networks of corner-sharing $\mathrm{CaN}_{5}$ trigonal bipyramids and double-layers of face-sharing $\mathrm{CaN}_{6}$ octahedra).

TABLE 1: Computed and Experimental Crystallographic Data of $\alpha-\mathrm{Ca}_{3} \mathrm{~N}_{2}$

\begin{tabular}{|c|c|c|c|c|c|c|c|}
\hline & & & \multicolumn{3}{|c|}{ GGA } & \multicolumn{2}{|c|}{$\operatorname{exptl}^{a}$} \\
\hline \multirow{5}{*}{\multicolumn{3}{|c|}{$\begin{array}{l}\text { space group } \\
Z \\
a / \mathrm{pm} \\
V / 10^{6} \mathrm{pm}^{3} \\
\rho / \mathrm{g} \mathrm{cm}^{-3}\end{array}$}} & \multicolumn{3}{|c|}{$\operatorname{Ia} \overline{3}$ (no. 206) } & \\
\hline & & & \multicolumn{3}{|c|}{16} & \multirow{2}{*}{\multicolumn{2}{|c|}{$114786(2)$}} \\
\hline & & & \multicolumn{3}{|c|}{1145.36} & & $5(2)$ \\
\hline & & & 150 & 2.55 & & 1512.4 & \\
\hline & & & 2.6 & & & 2.60 & \\
\hline atom & Wyc. & $x$ & $y$ & $z$ & $x$ & $y$ & $z$ \\
\hline Ca1 & $48 \mathrm{e}$ & 0.38965 & 0.15424 & 0.38269 & $0.389(1)$ & $0.153(1)$ & $0.382(1)$ \\
\hline N1 & $8 b$ & $1 / 4$ & $1 / 4$ & $1 / 4$ & $1 / 4$ & $1 / 4$ & $1 / 4$ \\
\hline $\mathrm{N} 2$ & $24 d$ & 0.96059 & 0 & $1 / 4$ & $0.960(2)$ & 0 & $1 / 4$ \\
\hline
\end{tabular}

${ }^{a} \operatorname{Ref} 37$.

coordinated (as in $\mathrm{Ca}_{3}{ }^{[4]} \mathrm{N}_{2}{ }^{[6]}$ ), in $\delta-\mathrm{Ca}_{3} \mathrm{~N}_{2}$ Ca exhibits a four-, five-, and six-fold coordination (tetrahedrally, quadratic prismatically, octahedrally) and $\mathrm{N}$ a six- and seven-fold coordination (octahedrally and seven-fold), the coordination description being $\left[\mathrm{Ca}_{2 / 3}{ }^{[4]} \mathrm{Ca}_{2 / 9}{ }^{[5]} \mathrm{Ca}_{1 / 9}{ }^{[6]} \mathrm{N}_{1 / 3}{ }^{[6]} \mathrm{N}_{2 / 3}{ }^{[7]}\right]$. For $\varepsilon-\mathrm{Ca}_{3} \mathrm{~N}_{2}$ coordination numbers are further increased to five (trigonal bibyramids) and six (octahedra) for $\mathrm{Ca}$ and eight for $\mathrm{N}$ (cubes) $\left(\mathrm{Ca}_{2 / 3}{ }^{[5]} \mathrm{Ca}_{1 / 3}{ }^{[6]} \mathrm{N}_{3 / 3}{ }^{[8]}\right.$ ). Given the sequence of the antistructures of bixbyite, corundum, and $\mathrm{Rh}_{2} \mathrm{O}_{3}$-II, yet another high-pressure phase with an (anti-)postperovskite structure would be rational. But when compressing $\mathrm{Ca}_{3} \mathrm{~N}_{2}$ in the post-perovskite structure (space group $\mathrm{Cmcm}$, no. 63), ${ }^{40}$ we found a distortion toward a higher hexagonal symmetry. This sixth candidate structure, termed $\lambda-\mathrm{Ca}_{3} \mathrm{~N}_{2}$, has been identified with space group $P 6_{3} / m m c$ (no. 194) (Figure 6). It exhibits a hitherto undetected structure of $\mathrm{Ca}_{3} \mathrm{~N}_{2}$ which is related to that of $\beta-\mathrm{Be}_{3} \mathrm{~N}_{2}$ (The Wyckoff positions for M1, M2, and $\mathrm{N} 1$ are the same, but $\mathrm{N} 2$ occupies the $2 \mathrm{~d}$ position in $\lambda-\mathrm{Ca}_{3} \mathrm{~N}_{2}$ and the $2 \mathrm{c}$ position in $\beta-\mathrm{Be}_{3} \mathrm{~N}_{2}$ ). ${ }^{41} \lambda-\mathrm{Ca}_{3} \mathrm{~N}_{2}$ exhibits partially increased coordination numbers for $\mathrm{Ca}$ and $\mathrm{N}$ compared to $\varepsilon-\mathrm{Ca}_{3} \mathrm{~N}_{2}$. Whereas the coordination polyhedra of Ca remain unchanged, the ratio of $\mathrm{CN}=5$ to $\mathrm{CN}=6$ shifts from $2: 1$ to $1: 2$. $N$ is now eight- and nine-fold coordinated (Figure 6). For all optimized structures the coordination numbers of the $\mathrm{M}^{2+}$ ions were determined by calculating effective coordination numbers $(\mathrm{ECoN})^{42}$ with MAPLE, ${ }^{43,44}$ in order to compare them to the data for the experimentally determined structures (if available). In Tables 1-6 we list the computed crystallographic data of our six polymorphs and compare them with available experimental values. For $\alpha-\mathrm{Ca}_{3} \mathrm{~N}_{2}$ we have also compared them to the results of previous calculations, which are in good accordance with our results. ${ }^{45,46}$

The calculated bond lengths $\mathrm{Ca}-\mathrm{N}\left(\alpha-\mathrm{Ca}_{3} \mathrm{~N}_{2}, 245-247 \mathrm{pm}\right.$; $\left.\beta-\mathrm{Ca}_{3} \mathrm{~N}_{2}, 241-253 \mathrm{pm} ; \gamma-\mathrm{Ca}_{3} \mathrm{~N}_{2}, 240-259 \mathrm{pm}\right)$ are all in the range of those in $\alpha-\mathrm{Ca}_{3} \mathrm{~N}_{2}\left(245-249 \mathrm{pm}^{37}\right)$ and $\beta-\mathrm{Ca}_{3} \mathrm{~N}_{2}$ $\left(242-252 \mathrm{pm}^{11}\right)$ and correspond well to the sum of the ionic
TABLE 2: Computed and Experimental Crystallographic Data of $\beta-\mathrm{Ca}_{3} \mathrm{~N}_{2}$

\begin{tabular}{|c|c|c|c|c|c|c|c|}
\hline & & & \multicolumn{3}{|c|}{ GGA } & \multicolumn{2}{|c|}{$\operatorname{exptl}^{a}$} \\
\hline \multirow{2}{*}{\multicolumn{3}{|c|}{$\begin{array}{l}\text { space group } \\
Z\end{array}$}} & \multicolumn{3}{|c|}{$R \overline{3} c$ (no. 167) } & \\
\hline \multirow{2}{*}{\multicolumn{3}{|c|}{$\begin{array}{l}Z \\
a / \mathrm{pm}\end{array}$}} & \multicolumn{3}{|c|}{6} & & \\
\hline & & & \multirow{2}{*}{\multicolumn{3}{|c|}{$\begin{array}{l}618.48 \\
1662.13\end{array}$}} & \multicolumn{2}{|c|}{618.94} \\
\hline \multicolumn{3}{|c|}{$c / \mathrm{pm}$} & & & & & 1.15 \\
\hline \multicolumn{3}{|c|}{$V / 10^{6} \mathrm{pm}^{3}$} & \multicolumn{3}{|c|}{550.61} & \multicolumn{2}{|c|}{551.11} \\
\hline \multicolumn{3}{|c|}{$\rho / \mathrm{g} \mathrm{cm}^{-3}$} & \multicolumn{2}{|c|}{2.68} & & \multicolumn{2}{|c|}{2.69} \\
\hline atom & Wyc. & $x$ & $y$ & $z$ & $x$ & $y$ & $z$ \\
\hline $\mathrm{Ca} 1$ & $18 \mathrm{e}$ & 0.30000 & 0 & 0.25 & 0.30005 & 0 & 0.25 \\
\hline N1 & $12 \mathrm{c}$ & 0 & 0 & 0.35349 & 0 & 0 & 0.35254 \\
\hline
\end{tabular}

${ }^{a} \operatorname{Ref} 11$.

TABLE 3: Computed Crystallographic Data of $\gamma-\mathrm{Ca}_{3} \mathrm{~N}_{2}$

\begin{tabular}{|c|c|c|c|c|}
\hline & & \multicolumn{3}{|c|}{ GGA } \\
\hline \multicolumn{2}{|r|}{ space group } & \multicolumn{3}{|c|}{ Pbcn (no. 60) } \\
\hline \multicolumn{2}{|r|}{$Z$} & \multicolumn{3}{|c|}{4} \\
\hline \multicolumn{2}{|r|}{$a / \mathrm{pm}$} & \multicolumn{3}{|c|}{620.30} \\
\hline \multicolumn{2}{|r|}{$b / \mathrm{pm}$} & \multicolumn{3}{|c|}{635.20} \\
\hline \multicolumn{2}{|r|}{$c / \mathrm{pm}$} & \multicolumn{3}{|c|}{895.97} \\
\hline \multicolumn{2}{|r|}{$V / 10^{6} \mathrm{pm}^{3}$} & \multicolumn{3}{|c|}{353.03} \\
\hline & $\rho / \mathrm{g} \mathrm{cm}^{-3}$ & & 2.79 & \\
\hline atom & Wyc. & $x$ & $y$ & $z$ \\
\hline $\mathrm{Ca} 1$ & $8 \mathrm{~d}$ & 0.60627 & 0.10513 & 0.84712 \\
\hline $\mathrm{Ca} 2$ & $4 c$ & 0.04498 & $1 / 4$ & 0 \\
\hline N1 & $8 \mathrm{~d}$ & 0.75278 & 0.03142 & 0.11210 \\
\hline
\end{tabular}

TABLE 4: Computed Crystallographic Data of $\delta-\mathrm{Ca}_{3} \mathrm{~N}_{2}$

\begin{tabular}{|c|c|c|c|c|}
\hline & & \multicolumn{3}{|c|}{ GGA } \\
\hline \multirow{8}{*}{\multicolumn{2}{|c|}{$\begin{array}{l}\text { space group } \\
Z \\
a / \mathrm{pm} \\
b / \mathrm{pm} \\
c / \mathrm{pm} \\
\beta / \mathrm{deg} \\
V / 10^{6} \mathrm{pm}^{3} \\
\rho / \mathrm{g} \mathrm{cm}^{-3}\end{array}$}} & \multicolumn{3}{|c|}{$C 2 / m$ (no. 12) } \\
\hline & & \multicolumn{3}{|c|}{6} \\
\hline & & \multicolumn{3}{|c|}{1504.98} \\
\hline & & \multicolumn{3}{|c|}{378.30} \\
\hline & & \multicolumn{3}{|c|}{934.90} \\
\hline & & \multicolumn{3}{|c|}{100.54} \\
\hline & & \multirow{2}{*}{\multicolumn{3}{|c|}{$\begin{array}{l}523.30 \\
2.82\end{array}$}} \\
\hline & & & & \\
\hline atom & Wyc. & $x$ & $y$ & $z$ \\
\hline $\mathrm{Ca} 1$ & $4 \mathrm{i}$ & 0.12567 & 0 & 0.27775 \\
\hline $\mathrm{Ca} 2$ & $4 \mathrm{i}$ & 0.32800 & $1 / 2$ & 0.03518 \\
\hline $\mathrm{Ca} 3$ & $4 \mathrm{i}$ & 0.28973 & $1 / 2$ & 0.37949 \\
\hline $\mathrm{Ca} 4$ & $4 \mathrm{i}$ & 0.46826 & 0 & 0.33945 \\
\hline $\mathrm{Ca} 5$ & $2 b$ & 0 & $1 / 2$ & 0 \\
\hline N1 & $4 \mathrm{i}$ & 0.14105 & $1 / 2$ & 0.48828 \\
\hline $\mathrm{N} 2$ & $4 \mathrm{i}$ & 0.18256 & $1 / 2$ & 0.13023 \\
\hline N3 & $4 \mathrm{i}$ & 0.46936 & $1 / 2$ & 0.18775 \\
\hline
\end{tabular}

radii (ionic radii after Shannon, $\Sigma \mathrm{Ca}^{[6]}-\mathrm{N}^{[4]}=246 \mathrm{pm} ;{ }^{47}$ ionic radii after Baur, $\Sigma \mathrm{Ca}^{[4]}-\mathrm{N}^{[6]}=246 \mathrm{pm} ; \sum \mathrm{Ca}^{[6]}-\mathrm{N}^{[8]}=257$ pm). ${ }^{48}$ For $\delta-\mathrm{Ca}_{3} \mathrm{~N}_{2}, \varepsilon-\mathrm{Ca}_{3} \mathrm{~N}_{2}$, and $\lambda-\mathrm{Ca}_{3} \mathrm{~N}_{2}$ the dispersion of bond lengths is larger $\left(\delta-\mathrm{Ca}_{3} \mathrm{~N}_{2}, 233-280 \mathrm{pm} ; \varepsilon-\mathrm{Ca}_{3} \mathrm{~N}_{2}\right.$, $\left.244-296 \mathrm{pm} ; \lambda-\mathrm{Ca}_{3} \mathrm{~N}_{2}, 224-330 \mathrm{pm}\right)$ with the longest $\mathrm{Ca}-\mathrm{N}$ distances in $\lambda-\mathrm{Ca}_{3} \mathrm{~N}_{2}$ being found for the two vertices of the $\mathrm{CaN}_{5}$ trigonal bipyramids, which are substantially reduced under pressure.

III.b. Total Energies, Densities, and Bulk Moduli. Referring to our GGA calculations at ambient pressure, $\alpha-\mathrm{Ca}_{3} \mathrm{~N}_{2}$ has the lowest energy of the four polymorphs $(-26.728 \mathrm{eV}$ per formula unit) and also the lowest density, $\rho=2.62 \mathrm{~g} \mathrm{~cm}^{-3}$ (exptl value $\left.2.61 \mathrm{~g} \mathrm{~cm}^{-3}\right) \cdot \beta-\mathrm{Ca}_{3} \mathrm{~N}_{2}$ is only about $0.072 \mathrm{eV}$ per formula unit higher in energy, but also about $2.3 \%$ denser (computed $2.68 \mathrm{~g} \mathrm{~cm}^{-3}$, matching exptl $\left.2.68 \mathrm{~g} \mathrm{~cm}^{-3}\right)$. The density of $\gamma-\mathrm{Ca}_{3} \mathrm{~N}_{2}\left(\rho=2.79 \mathrm{~g} \mathrm{~cm}^{-3}\right)$ is higher than that of both $\alpha-$ and 
TABLE 5: Computed Crystallographic Data of $\varepsilon-\mathrm{Ca}_{3} \mathbf{N}_{2}$

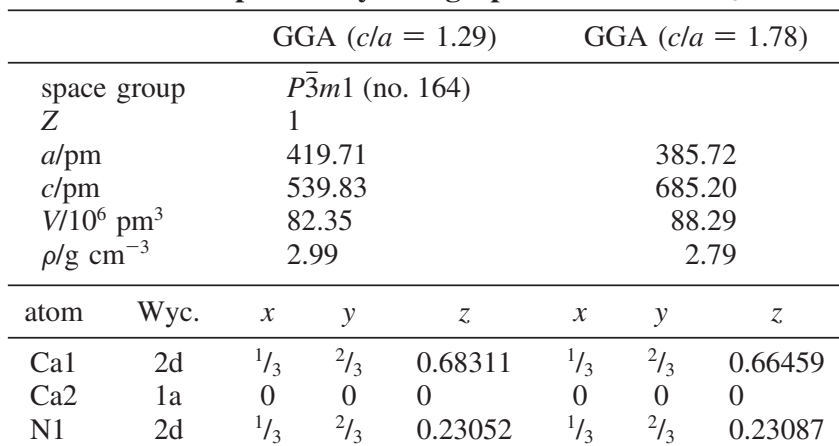

TABLE 6: Computed Crystallographic Data of $\lambda-\mathrm{Ca}_{3} \mathrm{~N}_{2}$

\begin{tabular}{|c|c|c|c|c|}
\hline & & \multicolumn{3}{|c|}{ GGA } \\
\hline \multirow{6}{*}{\multicolumn{2}{|c|}{$\begin{array}{l}\text { space group } \\
Z \\
a / \mathrm{pm} \\
c / \mathrm{pm} \\
V / 10^{6} \mathrm{pm}^{3} \\
\rho / \mathrm{g} \mathrm{cm}^{-3}\end{array}$}} & \multicolumn{3}{|c|}{$P 6_{3} / m m c$ (no. 194) } \\
\hline & & \multicolumn{3}{|c|}{2} \\
\hline & & \multicolumn{3}{|c|}{389.11} \\
\hline & & \multirow{2}{*}{\multicolumn{3}{|c|}{$\begin{array}{l}1318.63 \\
172.90\end{array}$}} \\
\hline & & & & \\
\hline & & \multicolumn{3}{|c|}{2.85} \\
\hline atom & Wyc. & $x$ & $y$ & $z$ \\
\hline $\mathrm{Ca} 1$ & $4 \mathrm{f}$ & $1 / 3$ & $2 / 3$ & 0.08620 \\
\hline $\mathrm{Ca} 2$ & $2 b$ & 0 & 0 & $1 / 4$ \\
\hline N1 & $2 \mathrm{a}$ & 0 & 0 & 0 \\
\hline $\mathrm{N} 2$ & $2 d$ & $2 / 3$ & $1 / 3$ & $1 / 4$ \\
\hline
\end{tabular}

$\beta-\mathrm{Ca}_{3} \mathrm{~N}_{2}$, about $6.4 \%$ and $4.0 \%$, respectively. The energy of $\gamma-\mathrm{Ca}_{3} \mathrm{~N}_{2}$ in its ground state comes out $0.163 \mathrm{eV}$ per formula unit higher with respect to $\alpha-\mathrm{Ca}_{3} \mathrm{~N}_{2} . \delta-\mathrm{Ca}_{3} \mathrm{~N}_{2}\left(\rho=2.79 \mathrm{~g} \mathrm{~cm}^{-3}\right)$ is $7.6 \%$ denser than $\alpha-\mathrm{Ca}_{3} \mathrm{~N}_{2}$ and $1.1 \%$ denser than $\gamma-\mathrm{Ca}_{3} \mathrm{~N}_{2}$. Its ground-state energy is $0.239 \mathrm{eV}$ above that of $\alpha-\mathrm{Ca}_{3} \mathrm{~N}_{2}$ and $0.077 \mathrm{eV}$ above that of $\gamma-\mathrm{Ca}_{3} \mathrm{~N}_{2} \cdot \varepsilon-\mathrm{Ca}_{3} \mathrm{~N}_{2}$ then is the polymorph with the highest density we found. With $\rho=2.99 \mathrm{~g} \mathrm{~cm}^{-3}$ it is about $14.1 \%$ denser than $\alpha-\mathrm{Ca}_{3} \mathrm{~N}_{2}, 7.2 \%$ denser than $\gamma-\mathrm{Ca}_{3} \mathrm{~N}_{2}$, and $5.7 \%$ denser than $\delta-\mathrm{Ca}_{3} \mathrm{~N}_{2}$. Its energy lays $0.850 \mathrm{eV}$ above that of $\alpha-\mathrm{Ca}_{3} \mathrm{~N}_{2}$ and $0.611 \mathrm{eV}$ above that of $\delta-\mathrm{Ca}_{3} \mathrm{~N}_{2}$. Finally, $\lambda-\mathrm{Ca}_{3} \mathrm{~N}_{2}$ is lower in density than $\varepsilon-\mathrm{Ca}_{3} \mathrm{~N}_{2}$ by $4.7 \%$, but it is 8.6\% denser than $\alpha-\mathrm{Ca}_{3} \mathrm{~N}_{2}$ and still $2.1 \%$ denser than $\gamma-\mathrm{Ca}_{3} \mathrm{~N}_{2}$ and $1.1 \%$ denser than $\delta-\mathrm{Ca}_{3} \mathrm{~N}_{2}$. The energy of $\lambda-\mathrm{Ca}_{3} \mathrm{~N}_{2}$ is 0.980 $\mathrm{eV}$ per formula units higher than that of $\alpha-\mathrm{Ca}_{3} \mathrm{~N}_{2}$ and $0.130 \mathrm{eV}$ per formula units higher than that of $\varepsilon-\mathrm{Ca}_{3} \mathrm{~N}_{2}$. The bulk moduli at ambient pressure of the first three phases increase with increasing density from $68 \mathrm{GPa}$ over 72 to $73 \mathrm{GPa}$ in the sequence of $\alpha-, \beta$-, and $\gamma-\mathrm{Ca}_{3} \mathrm{~N}_{2} . \delta-\mathrm{Ca}_{3} \mathrm{~N}_{2}$ exhibits an equilibrium bulk modulus $B_{0}$ of $67 \mathrm{GPa}, \varepsilon-\mathrm{Ca}_{3} \mathrm{~N}_{2}$ of $76 \mathrm{GPa}$, and $\lambda-\mathrm{Ca}_{3} \mathrm{~N}_{2}$ of $45 \mathrm{GPa}$.

III.c. $\boldsymbol{E}-\boldsymbol{V}$ Calculations and Resulting $\boldsymbol{\Delta} \boldsymbol{H}-\boldsymbol{p}$ Diagram. In Figure 7 we show the $E-V$ curves of our six structures of $\mathrm{Ca}_{3} \mathrm{~N}_{2}$. We converted the $E-V$ data into the enthalpy-pressure phase diagram shown in Figure 8 by standard methods.

With respect to enthalpy, it turns out that $\alpha-\mathrm{Ca}_{3} \mathrm{~N}_{2}$ is the most stable polymorph of $\mathrm{Ca}_{3} \mathrm{~N}_{2}$ for pressures up to $5 \mathrm{GPa}$, at which it will transform to $\gamma-\mathrm{Ca}_{3} \mathrm{~N}_{2}$. $\beta-\mathrm{Ca}_{3} \mathrm{~N}_{2}$, on the other hand, does not appear as a valid high-pressure phase from our calculations, which refer to $0 \mathrm{~K}$ temperature. Its appearance, we suggest, is likely due to entropy effects that impact the Gibbs energy $\Delta G$ at higher temperatures. Once $\gamma-\mathrm{Ca}_{3} \mathrm{~N}_{2}$ is formed, it will remain stable up to about $10 \mathrm{GPa}$. At this pressure the monoclinic structure of $\delta-\mathrm{Ca}_{3} \mathrm{~N}_{2}$ becomes the most stable polymorph of $\mathrm{Ca}_{3} \mathrm{~N}_{2}$. When pressures exceeding $27 \mathrm{GPa}$ are reached, hexagonal $\varepsilon-\mathrm{Ca}_{3} \mathrm{~N}_{2}$ is lower in enthalpy and will consequently form. Above $38 \mathrm{GPa}, \lambda-\mathrm{Ca}_{3} \mathrm{~N}_{2}$ becomes lower in enthalpy.

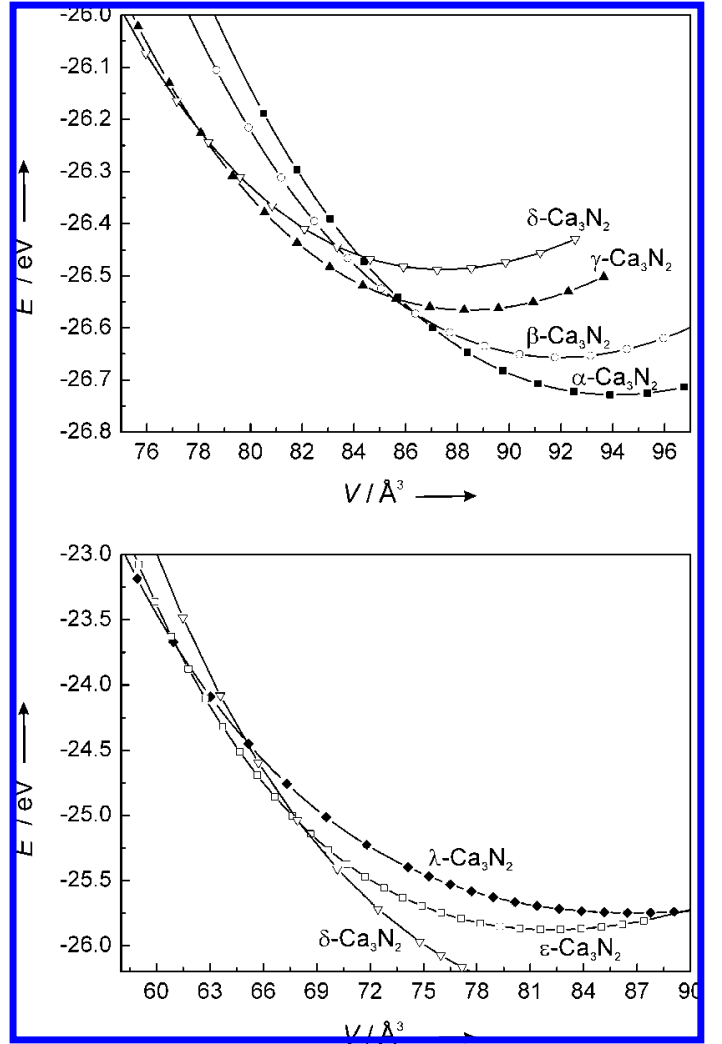

Figure 7. $E-V$ diagrams for six phases of $\mathrm{Ca}_{3} \mathrm{~N}_{2}$ : (top) $\alpha-\mathrm{Ca}_{3} \mathrm{~N}_{2}$, $\beta-\mathrm{Ca}_{3} \mathrm{~N}_{2}, \gamma-\mathrm{Ca}_{3} \mathrm{~N}_{2}, \delta-\mathrm{Ca}_{3} \mathrm{~N}_{2}$; (bottom) (continuation of top, $\alpha$-, $\beta$-, and $\gamma$-phases omitted for clarity) $\delta-\mathrm{Ca}_{3} \mathrm{~N}_{2}, \varepsilon-\mathrm{Ca}_{3} \mathrm{~N}_{2}, \lambda-\mathrm{Ca}_{3} \mathrm{~N}_{2}$. The line is a fit to the data according to Murnaghan's EOS.

In total, we thus propose four new high-pressure phases of $\mathrm{Ca}_{3} \mathrm{~N}_{2}$. The sequence of structures together with transition pressures and density increases are illustrated in Figure 9.

\section{Discussion}

We succeeded in identifying several promising candidates for high-pressure phases of $\mathrm{Ca}_{3} \mathrm{~N}_{2}$. According to our calculations, $\gamma-\mathrm{Ca}_{3} \mathrm{~N}_{2}$ is the thermodynamical stable modification between 5 and $10 \mathrm{GPa}$. Above $10 \mathrm{GPa}$, another high-pressure phase $-\delta$ $\mathrm{Ca}_{3} \mathrm{~N}_{2}-$ becomes lower in enthalpy than $\gamma-\mathrm{Ca}_{3} \mathrm{~N}_{2}$, easily accessible in today's high-pressure experimental setups. $\gamma-\mathrm{Ca}_{3} \mathrm{~N}_{2}$ remains thermodynamical stable up to $27 \mathrm{GPa}$, when $\varepsilon-\mathrm{Ca}_{3} \mathrm{~N}_{2}$ comes into existence, finally followed by $\lambda-\mathrm{Ca}_{3} \mathrm{~N}_{2}$ above $38 \mathrm{GPa}$. The complete pressure range is attainable in diamond anvil cell (DAC) experiments, and the search for high-pressure phases of $\mathrm{Ca}_{3} \mathrm{~N}_{2}$ should provide a fertile soil for discoveries.

About 50 years ago, a high-pressure phase of $\mathrm{Ca}_{3} \mathrm{~N}_{2}$ with orthorhombic structure has been mentioned by Bradley et al. ${ }^{7}$ It was synthesized at $4.6 \mathrm{GPa}$ (and $1800{ }^{\circ} \mathrm{C}$ ), which matches the transition pressure we computed for $\alpha-\mathrm{Ca}_{3} \mathrm{~N}_{2}$ into $\gamma-\mathrm{Ca}_{3} \mathrm{~N}_{2}$ very closely. The cell parameters reported at that time, however, do not agree with the data we propose for $\gamma-\mathrm{Ca}_{3} \mathrm{~N}_{2}$. Nevertheless, this concurrence strongly motivates experiments designated to elucidate the high-pressure behavior of $\mathrm{Ca}_{3} \mathrm{~N}_{2}$.

Although the transition of $\alpha-\mathrm{Ca}_{3} \mathrm{~N}_{2}$ into $\gamma-\mathrm{Ca}_{3} \mathrm{~N}_{2}$ does not affect the coordination of $\mathrm{Ca}$ and $\mathrm{N}$, coordination numbers are successively increased during transforming into $\delta-, \varepsilon_{-}^{-}$, and $\lambda-\mathrm{Ca}_{3} \mathrm{~N}_{2}$. The average coordination number for $\mathrm{Ca}$ increases from $4\left(\alpha-, \beta-, \gamma-\mathrm{Ca}_{3} \mathrm{~N}_{2}\right)$ to $4.44\left(\delta-\mathrm{Ca}_{3} \mathrm{~N}_{2}\right)$ to $5.33\left(\varepsilon-\mathrm{Ca}_{3} \mathrm{~N}_{2}\right)$ to $5.67\left(\lambda-\mathrm{Ca}_{3} \mathrm{~N}_{2}\right)$. The average coordination number for $\mathrm{N}$ increases from $6\left(\alpha-, \beta-, \gamma-\mathrm{Ca}_{3} \mathrm{~N}_{2}\right)$ to $6.67\left(\delta-\mathrm{Ca}_{3} \mathrm{~N}_{2}\right)$ to $8(\varepsilon-$ $\left.\mathrm{Ca}_{3} \mathrm{~N}_{2}\right)$ to $8.67\left(\lambda-\mathrm{Ca}_{3} \mathrm{~N}_{2}\right)$. 


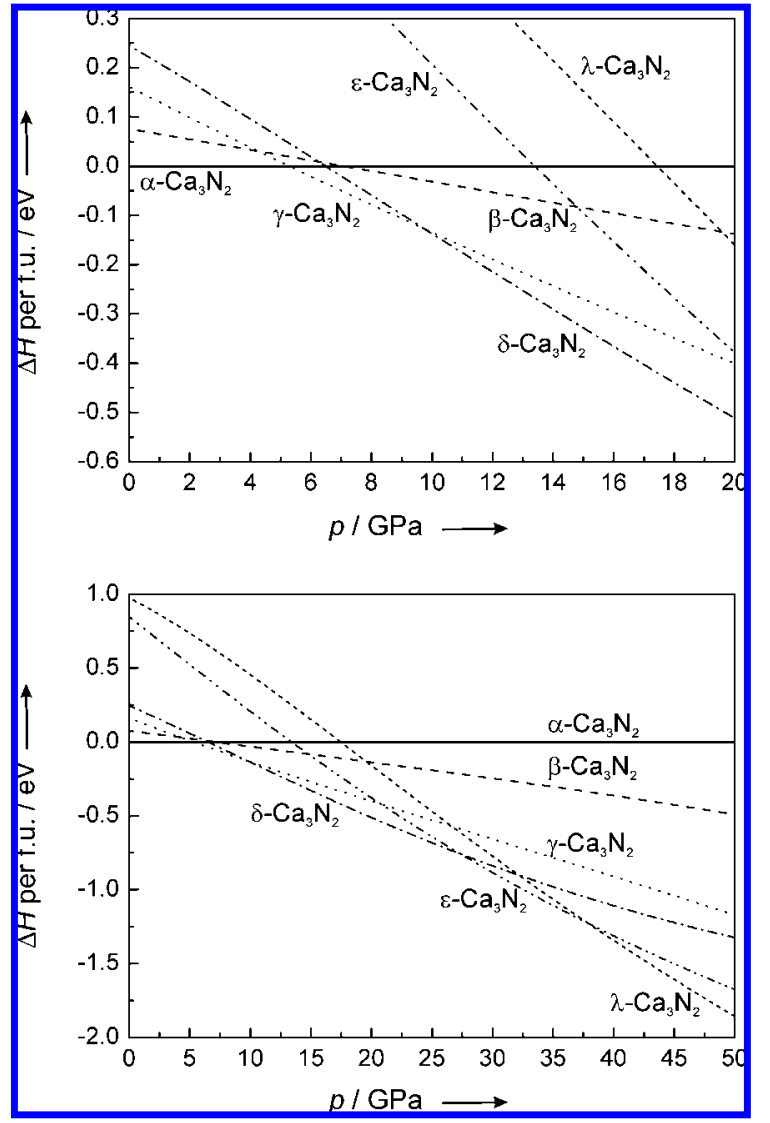

Figure 8. Enthalpy-pressure diagrams for the transition of $\alpha-\mathrm{Ca}_{3} \mathrm{~N}_{2}$ into $\beta-\mathrm{Ca}_{3} \mathrm{~N}_{2}\left(p_{\mathrm{t}}=6.5 \mathrm{GPa}\right), \gamma-\mathrm{Ca}_{3} \mathrm{~N}_{2}\left(p_{\mathrm{t}}=5.0 \mathrm{GPa}\right), \delta-\mathrm{Ca}_{3} \mathrm{~N}_{2}\left(p_{\mathrm{t}}=\right.$ $10 \mathrm{GPa}), \varepsilon-\mathrm{Ca}_{3} \mathrm{~N}_{2}\left(p_{\mathrm{t}}=27 \mathrm{GPa}\right)$, and $\lambda-\mathrm{Ca}_{3} \mathrm{~N}_{2}\left(p_{\mathrm{t}}=38 \mathrm{GPa}\right)$ : (top) zoom-in on the transitions of $\alpha-\mathrm{Ca}_{3} \mathrm{~N}_{2}$ into $\gamma-\mathrm{Ca}_{3} \mathrm{~N}_{2}$ and $\gamma-\mathrm{Ca}_{3} \mathrm{~N}_{2}$ into $\delta-\mathrm{Ca}_{3} \mathrm{~N}_{2}$.

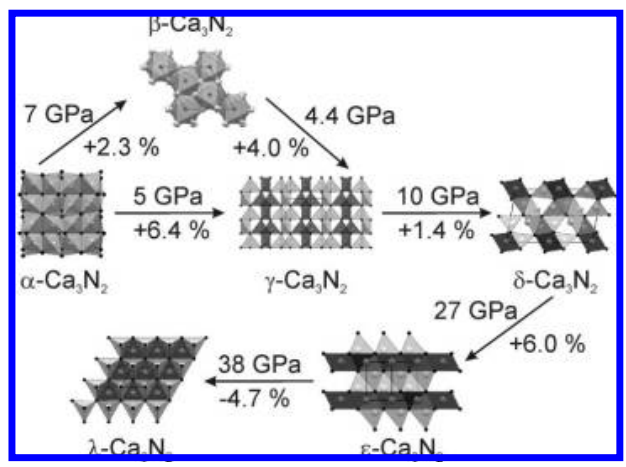

Figure 9. Sequence of structures of $\mathrm{Ca}_{3} \mathrm{~N}_{2}$ together with transition pressures and changes in density.

A constant increase in density is attained by every phase transition up to $\varepsilon-\mathrm{Ca}_{3} \mathrm{~N}_{2}$. Remarkably, $\lambda-\mathrm{Ca}_{3} \mathrm{~N}_{2}$ is lower in density than $\varepsilon-\mathrm{Ca}_{3} \mathrm{~N}_{2}$ at ambient pressure, although $\lambda-\mathrm{Ca}_{3} \mathrm{~N}_{2}$ succeeds the $\varepsilon$-phase at higher pressure. Although this finding is counterintuitive-one expects a high-pressure phase to be denser then a phase adopted at lower pressure-the reason is based in a very different behavior of density under pressure: $\lambda-\mathrm{Ca}_{3} \mathrm{~N}_{2}$ simply becomes denser than $\varepsilon-\mathrm{Ca}_{3} \mathrm{~N}_{2}$ above $11 \mathrm{GPa}$ (Figure 10).

The structural developments are somewhat complicated by a strong response of the $c / a$ ratio in $\varepsilon-\mathrm{Ca}_{3} \mathrm{~N}_{2}$ to the applied pressure. Note that above $12 \mathrm{GPa} \varepsilon-\mathrm{Ca}_{3} \mathrm{~N}_{2}$ with a cla ratio of 1.29 is more favorable (corresponding to an anti- $\mathrm{Ni}_{2} \mathrm{Al}_{3}$-type structure $^{39}$ ), whereas below $12 \mathrm{GPa}$ the structure suddenly expands to a cla ratio of 1.78 (denoted $\varepsilon^{\prime}$ and corresponding to

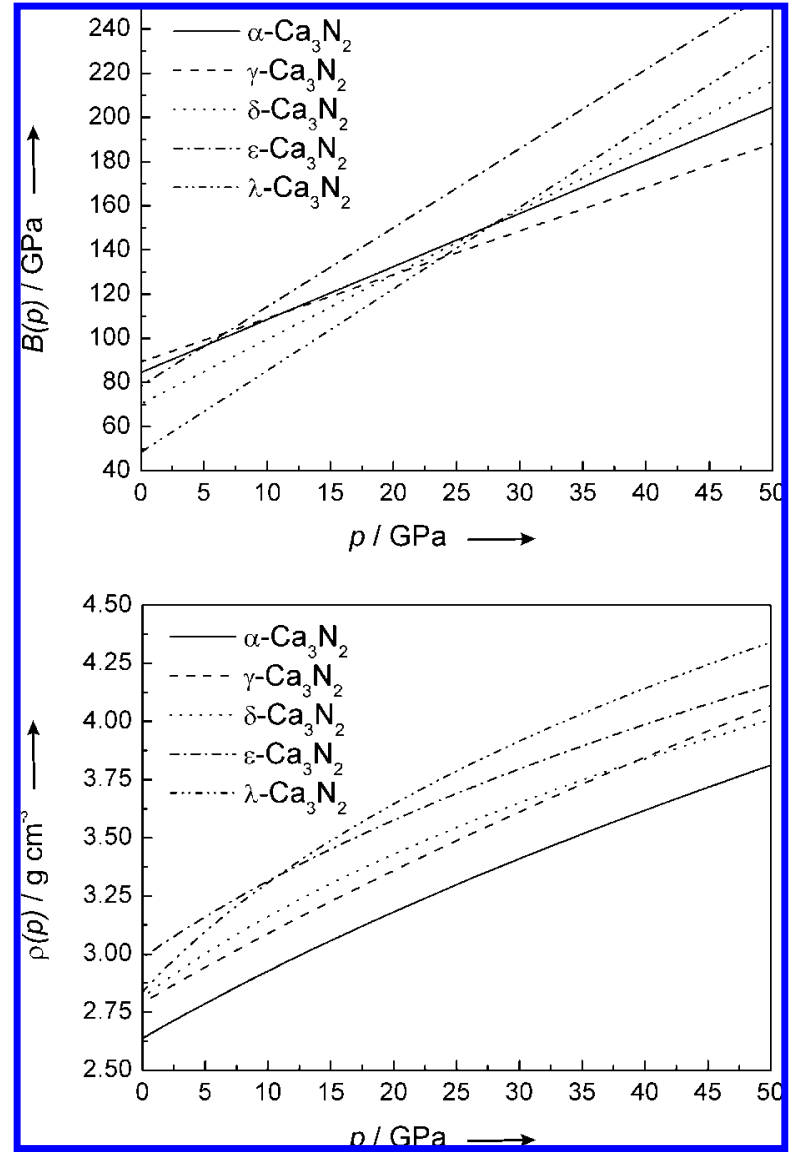

Figure 10. Pressure dependency of the bulk modulus $B$ (top) and the density $\rho$ (bottom) of the high-pressure phases of $\mathrm{Ca}_{3} \mathrm{~N}_{2}$.

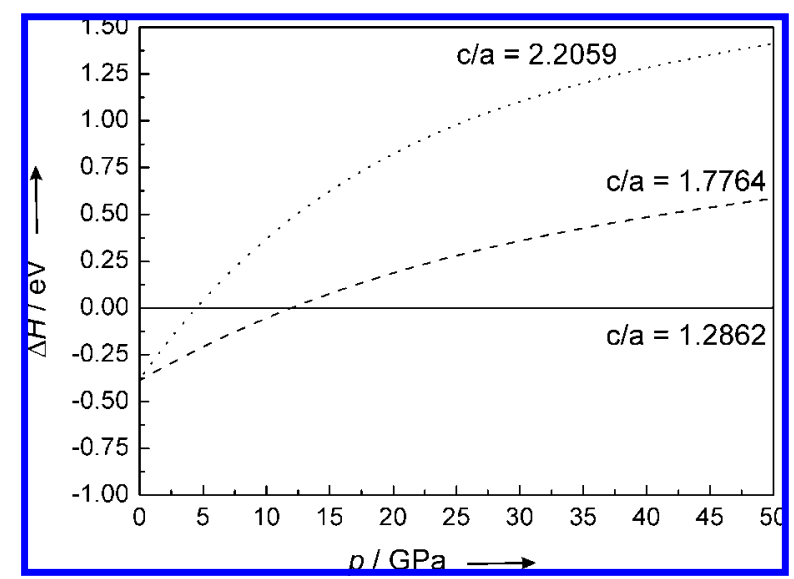

Figure 11. Enthalpy-pressure diagram of $\varepsilon-\mathrm{Ca}_{3} \mathrm{~N}_{2}$ for different fixed cla ratios.

a anti- $\mathrm{La}_{2} \mathrm{O}_{3}$-type structure, ${ }^{39}$ see Table 5). Computations with fixed ratio $c / a$ clearly indicated the crossover within this (anti)A-sesquioxide structure type (Figure 11).

When the zero-pressure bulk moduli of the different phases are compared, we see that $B_{0}$ increases from 68 to $73 \mathrm{GPa}$ along the sequence $\alpha-, \beta$-, and $\gamma-\mathrm{Ca}_{3} \mathrm{~N}_{2}$ (Table 7). It then decreases to $67 \mathrm{GPa}$ for $\delta-\mathrm{Ca}_{3} \mathrm{~N}_{2}$, increases to $76 \mathrm{GPa}$ for $\varepsilon-\mathrm{Ca}_{3} \mathrm{~N}_{2}$, and finally, drops to $45 \mathrm{GPa}$ for $\lambda-\mathrm{Ca}_{3} \mathrm{~N}_{2}$. Note that $B_{0}$ of $\varepsilon-\mathrm{Ca}_{3} \mathrm{~N}_{2}$ turns out even lower than that of $\alpha-\mathrm{Ca}_{3} \mathrm{~N}_{2}$ (68 GPa). Consequently, $\lambda-\mathrm{Ca}_{3} \mathrm{~N}_{2}$ should be the most compressible and $\varepsilon-\mathrm{Ca}_{3} \mathrm{~N}_{2}$ the least compressible of all discussed modifications of $\mathrm{Ca}_{3} \mathrm{~N}_{2}$. This also reflects the fact that $\lambda-\mathrm{Ca}_{3} \mathrm{~N}_{2}$ becomes denser under pressure than $\varepsilon-\mathrm{Ca}_{3} \mathrm{~N}_{2}$, since it is more compressible, and 
TABLE 7: $E_{0}, V_{0}, B_{0}, \rho$, and Band Gap for $\alpha-, \beta-, \gamma-, \delta-, \varepsilon-$, and $\lambda-\mathrm{Ca}_{3} \mathrm{~N}_{2}$

\begin{tabular}{lcccccc}
\hline & $\begin{array}{c}E_{0} \text { per } \\
\text { f.u./eV }\end{array}$ & $\begin{array}{c}V_{0} \text { per } \\
\text { f.u./10 }\end{array} \mathrm{pm}^{3}$ & $\begin{array}{c}B_{0} / \\
\mathrm{GPa}\end{array}$ & $\begin{array}{c}\rho / \mathrm{g} \\
\mathrm{cm}^{-1}\end{array}$ & $\begin{array}{c}\text { band gap/ } \\
\mathrm{eV}(\mathrm{GGA})\end{array}$ & $\begin{array}{c}\text { band gap/ } \\
\mathrm{eV}(\mathrm{LDA})\end{array}$ \\
\hline$\alpha-\mathrm{Ca}_{3} \mathrm{~N}_{2}$ & -26.728 & 93.91 & 68 & 2.62 & 1.16 & 1.25 \\
$\beta-\mathrm{Ca}_{3} \mathrm{~N}_{2}$ & -26.657 & 91.77 & 72 & 2.68 & 0.81 & 0.91 \\
$\gamma-\mathrm{Ca}_{3} \mathrm{~N}_{2}$ & -26.566 & 88.26 & 73 & 2.79 & 1.36 & 1.53 \\
$\delta-\mathrm{Ca}_{3} \mathrm{~N}_{2}$ & -26.489 & 87.22 & 67 & 2.82 & 1.42 & 1.65 \\
$\varepsilon-\mathrm{Ca}_{3} \mathrm{~N}_{2}$ & -25.878 & 82.35 & 76 & 2.99 & 0.99 & - \\
$\lambda-\mathrm{Ca}_{3} \mathrm{~N}_{2}$ & -25.748 & 86.46 & 45 & 2.85 & 1.46 & 1.78
\end{tabular}

therefore the same change in pressure $\Delta p$ results in a larger volume change $\Delta V$ in $\lambda-\mathrm{Ca}_{3} \mathrm{~N}_{2}$ than in $\varepsilon-\mathrm{Ca}_{3} \mathrm{~N}_{2}$.

The development of the bulk moduli under pressure for all considered high-pressure polymorphs is shown in Figure 10.

All high-pressure transitions of $\mathrm{Ca}_{3} \mathrm{~N}_{2}$ should be easily detectable via X-ray diffraction experiments (ex situ and in situ), as the powder patterns of all phases are quite different. Simulated powder patterns for all compounds at the respective transition pressures can be found in the Supporting Information.

In our calculations, $\beta-\mathrm{Ca}_{3} \mathrm{~N}_{2}$ does not appear as a valid highpressure phase of $\mathrm{Ca}_{3} \mathrm{~N}_{2}$, since it is always found to be higher in enthalpy than either $\alpha-, \gamma-, \delta-, \varepsilon-$, or $\lambda-\mathrm{Ca}_{3} \mathrm{~N}_{2}$. The transition pressure of $\alpha-\mathrm{Ca}_{3} \mathrm{~N}_{2}$ into $\beta-\mathrm{Ca}_{3} \mathrm{~N}_{2}$ is calculated to $7 \mathrm{GPa}$ and, therefore, higher than the transition pressure of $\alpha-\mathrm{Ca}_{3} \mathrm{~N}_{2}$ into $\gamma-\mathrm{Ca}_{3} \mathrm{~N}_{2}(5 \mathrm{GPa})$. Moreover, it is higher than the transition pressure of $\beta-\mathrm{Ca}_{3} \mathrm{~N}_{2}$ into $\gamma-\mathrm{Ca}_{3} \mathrm{~N}_{2}(4.4 \mathrm{GPa})$. Why can $\beta-\mathrm{Ca}_{3} \mathrm{~N}_{2}$ then be synthesized at all? Its existence may well be attributed to temperature effects and the influence of entropy on the Gibbs energy. Although entropy differences may have several sources, the amount of defects occurring in $\beta-\mathrm{Ca}_{3} \mathrm{~N}_{2}$ are expected to dominate over differences in vibrational entropy. ${ }^{11}$ For crystals containing point defects, the equation for the Gibbs energy $G$ $=H-T S$ has to be rewritten to $G=H_{0}-T S_{0}+n_{\mathrm{D}}\left(H_{\mathrm{D}}^{\mathrm{f}}-\right.$ $\left.T S_{\mathrm{D}}^{\mathrm{f}}\right)-k T\left(\ln W_{\mathrm{D}}\right)$, where $H_{0}-T S_{0}$ denotes the Gibbs energy of the perfect crystal, $n_{\mathrm{D}}$ is the number of defects, $H_{\mathrm{V}}^{\mathrm{f}}$ is the enthalpy of defect formation, $S_{\mathrm{D}}^{\mathrm{f}}$ is the thermal entropy, and $k T\left(\ln W_{\mathrm{D}}\right)$ is the configurational entropy. These additional terms to the Gibbs energy are not negligible for solids containing a significant defect concentration. Given the small enthalpy difference between $\alpha$ - and $\beta-\mathrm{Ca}_{3} \mathrm{~N}_{2}$ they may have a substantial influence on the Gibbs energy and, thus, on the phase development.

\section{Conclusion}

We investigated a manifold of possible structures of highpressure phases of calcium nitride, $\mathrm{Ca}_{3} \mathrm{~N}_{2}$, to elucidate the pressure-dependent phase diagram of $\mathrm{Ca}_{3} \mathrm{~N}_{2}$. Four candidate structures, anti- $\mathrm{Rh}_{2} \mathrm{O}_{3}-\mathrm{II}\left(\gamma-\mathrm{Ca}_{3} \mathrm{~N}_{2}\right)$, anti-B-sesquioxide $(\delta$ $\left.\mathrm{Ca}_{3} \mathrm{~N}_{2}\right)$, anti-C-sesquioxide $\left(\varepsilon-\mathrm{Ca}_{3} \mathrm{~N}_{2}\right)$, and a hitherto undetected hexagonal structure type $\left(\lambda-\mathrm{Ca}_{3} \mathrm{~N}_{2}\right)$ are found to become lower in enthalpy under pressure than $\alpha-\mathrm{Ca}_{3} \mathrm{~N}_{2}$. Although $\alpha-, \beta$-, and $\gamma-\mathrm{Ca}_{3} \mathrm{~N}_{2}$ exhibit the same coordination numbers for $\mathrm{Ca}$ and $\mathrm{N}$, the coordination numbers increase toward $\delta$-, $\varepsilon$-, and $\lambda-\mathrm{Ca}_{3} \mathrm{~N}_{2}$. $\alpha-\mathrm{Ca}_{3} \mathrm{~N}_{2}$ will first transform into $\gamma-\mathrm{Ca}_{3} \mathrm{~N}_{2}$ at $5 \mathrm{GPa}$, which in turn transforms into $\delta-\mathrm{Ca}_{3} \mathrm{~N}_{2}$ at $10 \mathrm{GPa}$. At $27 \mathrm{GPa} \varepsilon-\mathrm{Ca}_{3} \mathrm{~N}_{2}$ becomes the most stable polymorph of $\mathrm{Ca}_{3} \mathrm{~N}_{2}$, surpassed above $39 \mathrm{GPa}$ by $\lambda-\mathrm{Ca}_{3} \mathrm{~N}_{2}$. This very rich high-pressure chemistry of $\mathrm{Ca}_{3} \mathrm{~N}_{2}$ we propose indeed will motivate detailed experiments.

Acknowledgment. Information on $\beta-\mathrm{Ca}_{3} \mathrm{~N}_{2}$ provided by $\mathrm{Dr}$. P. Höhn, Max-Planck-Institut für Chemische Physik fester Stoffe, Dresden, is gratefully appreciated. Financial support by the Deutsche Forschungsgemeinschaft (priority program SPP 1236, projects SCHN 377/13 and KR 1805/10 and Heisenberg program $\mathrm{Kr} 1805 / 9)$ as well as the Fonds der Chemischen Industrie (FCI), Germany, is gratefully acknowledged. The authors further thank the Leibniz Rechenzentrum, Munich for computational resources on the Linux Cluster System, as well as the Texas Advanced Computing Center at Austin.

Supporting Information Available: Simulated X-ray powder patterns of the different calculated polymorphs of $\mathrm{Ca}_{3} \mathrm{~N}_{2}$ at the respective transition pressures. This material is available free of charge via the Internet at http://pubs.acs.org.

\section{References and Notes}

(1) Moissan, H. C. R. Hebd. Seances Acad. Sci. 1898, 127, 497-501.

(2) For example: (a) Jian, J. K.; Wang, G.; Wang, C.; Yuan, W. X.; Chen, X. L. J. Crvst. Growth 2006, 291, 72-76. (b) Hampshire, S.; Park, H. K.; Thompson, D. P.; Jack, K. H. Nature 1978, 274, 880-882. (c) Vennos, D. A.; Badding, M. E.; DiSalvo, F. J. Inorg. Chem. 1990, 29, 4059-4062. (d) Chern, Y. M.; Vennos, D. A.; DiSalvo, F. J. J. Solid State Chem. 1992, 96, 415-425. (e) Schnick, W.; Schultz-Coulon, V. Angew. Chem. 1993, 105, 308-309; Angew. Chem., Int. Ed. Engl. 1993, 32, 280-281. (f) Schultz-Coulon, V.; Schnick, W. Z. Naturforsch., B: Chem. Sci. 1995, 50, 619-622. (g) Rohrer, F. E.; Nesper, R. J. Solid State Chem. 1998, 135, 194-200. (h) Henry, P. F.; Weller, M. T. Angew. Chem. 1998, 110, 30403041; Angew. Chem., Int. Ed. 1998, 37, 2855-2857.

(3) (a) Willners, H. Improving the Quality of Steel. Svensk Patenttidning SE 115621 19460108, 1946. (b) Desulfurizing and Dephosphorizing Agents for Steel and Cast Iron. Jpn. Kokao Tokkyo Koho JP 55094432 19800717, 1980. (c) Kobayashi, H. Refining of Molten Steel. Jpn. Kokai Tokkyo Koho JP 03006314, A, 1991.

(4) For example: (a) Yin, 1.-W.; Li, M.-S.; Liu, Y.-X.; Xu, B.; Sui, J.-L.; Qi, Y.-X. Adv. Mater. 2003, 15, 720-723. (b) Bocquillon, G.; LoriersSusse, C.; Loriers, J. J. Mater. Sci. 1993, 28, 3547-3456.

(5) Franck, H. H.; Beredig, M. A.; Hoffmann, G. Naturwississenschaften 1933, 21, 330-331.

(6) Hartmann, H.; Fröhlich, H. J. Z. Anorg. Allg. Chem. 1934, 218 , 190-192.

(7) Bradley, R. S.; Munro, D. C.; Whitfield, M. J. Inorg. Nucl. Chem. 1966, 28, 1803-1812. 322 .

(8) Stackelberg, M. v.; Paulus, R. Z. Phys. Chem. 1933, 22 (B), 365-

(9) Laurent, Y.; Lang, J.; Le Bihan, M. T. Acta Crystallogr.. Sect. B 1968, 24, 494-499.

(10) Reckeweg, O.; DiSalvo, F. J. Z. Anorg. Allg. Chem. 2001, 627, 371-377.

(11) Höhn, P. Chem. Eur. J., submitted for publication, 2008.

(12) Santillan, J.; Shim, S.-H.; Shen, G.; Prakapenka, V. B. Geophvs. Res. Lett. 2006, 33, L15307/1-L15307/5.

(13) Tsuchiya, J.; Tsuchiya, T.; Wentzcovitch, R. M. Phvs. Rev. B 2005, 72, 020103/1-020103/4

(14) Duan, W.; Wentzcovitch, R. M.; Thomson, K. T. Phvs. Rev. B 1998, 57, 10363-10369.

(15) Lin, J.-F.; Degtyareva, O.; Prewitt, C. T.; Dera, P.; Sata, N.; Gregoryanz, E.; Mao, H.-K.; Hemley, R. J. Nat. Mater. 2004, 3, 389-392. (16) Funamori, N.; Jeanloz, R. Science 1997, 278, 1109-1111.

(17) Mashimo, T.; Tsumoto, K.; Nakamura, K.; Noguchi, Y.; Fukuoka, K.; Syono, Y. Geophvs. Res. Lett. 2000, 27, 2021-2024.

(18) Cynn, H.; Isaak, D. G.; Cohen, R. E.; Nicol, M. F.; Anderson, O. L. Am. Mineral. 1990, 75, 439-442.

(19) Morton, F. C.; Cohen, R. E. Am. Mineral. 1994, 79, 789-792.

(20) Thomson, K. T.; Wentzcovitch, R. M.; Bukowinski, M. S. T. Science 1996, 274, 1880-1882.

(21) (a) Oganov, A. R.; Ono, S. Proc. Natl. Acad. Sci. U.S.A. 2005, 102, 10828-10831. (b) Ono, S.; Oganov, A. R.; Koyama, T.; Shimizu, H. Earth Planet. Sci. Lett. 2006, 246, 326-335.

(22) Caracas, R.; Cohen, R. E. Phvs. Rev. B 2007, 76, 184104/1-184104/ (23) Shannon, R. D.; Prewitt, C. T. J. Solid State Chem. 1970, 2, 134-
136.

(24) Rozenberg, Kh. G.; Dubrovinsky, L. S.; Pasternak, M. P.; Naaman, O.; Le Bihan, T.; Ahuja, R. Phvs. Rev.B 2002, 65, 064112/1-064112/8. (25) Shim, S.-H.; Duffy, T. S. Am. Mineral. 2002, 87, 318-326.

(26) Ono, S.; Ohishi, Y. J. Phys. Chem. Solids 2005, 66, 1714-1720.

(27) (a) Gurlo, A.; Kroll, P.; Riedel, R. Chem. Eur. J. 2008, 14, 33063310. (b) Caracas, R.; Cohen, R. E. Phys. Rev. 2007, 76, 184101/1-184101/ 8.

(28) (a) Yusa, H.; Tsuchiya, T.; Sata, N.; Ohishi, Y. Phys. Rev. B 2008, 77, 0641071-9. (b) Gurlo, A.; Dzivenko, D.; Kroll, P.; Riedel, R. Phvs. Status Solidi RRL 2008, 2, 269-271.

(29) Hohenberg, P.; Kohn, W. Phvs. Rev. B 1964, 136, 864-871. 
(30) Kresse, G. Phys. Rev. B 1993, 47, 558-561; 1994, 49, 1425114269.

(31) Kresse, G.; Furthmüller, J. Comput. Mater. Sci. 1996, 6, 15-50.

(32) Kresse, G.; Furthmüller, J. Phvs. Rev. B 1996, 54, 11169-11186.

(33) Perdew, J. P. In Electronic Structures of Solids '91; Ziesche, P., Eschrig, H., Eds.; Akademie Verlag: Berlin, 1991.

(34) Kresse, G.; Joubert, J. Phvs. Rev. B 1999, 59, 1758-1775.

(35) Monkhorst, H. J.; Pack, J. D. Phys. Rev. B 1976, 13, 5188-5192.

(36) Murnaghan, F. D. Proc. Natl. Acad. Sci. U.S.A. 1944, 30, 244 247.

(37) Laurent, Y.; Lang, J.; LeBihan, M. Th. Acta Crystallogr., Sect. B 1968, 24, 494-499.

(38) Cromer, D. T. J. Phvs. Chem. 1957, 61, 753-755.

(39) (a) $\mathrm{La}_{2} \mathrm{O}_{3}$ : Barbezat, S.; Loriers, J. C. R. Hebd. Seances Acad. Sci. 1952, 234, 1978-1980. (b) $\mathrm{Ni}_{2} \mathrm{Al}_{3}$ : Bradley, A. J.; Taylor, A. Philos. Mag. 1937, 23, 1049-1067.

(40) Rodi, F.; Babel, D. Z. Anorg. Allg. Chem. 1965, 336, 17-23.
(41) (a) Eckerlin, P.; Rabenau, A. Z. Anorg. Allg. Chem. 1960, 304, 218-229. (b) Hall, D.; Gurr, G. E.; Jeffrey, G. A. Z. Anorg. Allg. Chem. 1969, 369, 108-112.

(42) Hoppe, R. Angew. Chem. 1970, 82, 7-16; Angew. Chem., Int. Ed. Engl. 1970, 9, 25-34.

(43) (a) Hoppe, R. Angew. Chem. 1966, 78, 52-63; Angew. Chem., Int. Ed. Engl. 1966, 5, 95-106. (b) Hoppe, R. Z. Naturforsch., A: Phys. Sci. 1995, 50, 555-567. (c) Weiss, C.; Hoppe, R. Z. Anorg. Allg. Chem. 1996, $622,1019-1026$.

(44) Hübenthal, R. MAPLE, Madlung Part of Lattice Energy (Program), version 4; University of Giessen: Giessen, Germany, 1993.

(45) Mokhtari, A.; Akbarzadeh, H. Phvsica B 2003, 337, 122-129.

(46) Orhan, E.; Jobic, S.; Brec, R.; Marchand, R.; Saillard, J.-Y. J. Mater. Chem. 2002, 12, 2475-2479.

(47) Shannon, R. D. Acta Crustallogr.. Sect. A 1976, 32, 751-767.

(48) Baur, W. H. Crvstallogr. Rev. 1987, 1, 59-83.

JP8077002 